\title{
Pregnancy during Residency
}

\section{Citation}

Sayres, Maureen, Grace Wyshak, Geraldine Denterlein, Roberta Apfel, Eleanor Shore, and Daniel Federman. 1986. “Pregnancy During Residency.” N Engl J Med 314 (7) (February 13): 418-423. doi:10.1056/nejm198602133140705.

\section{Published Version}

doi:10.1056/NEJM198602133140705

\section{Permanent link}

http://nrs.harvard.edu/urn-3:HUL.InstRepos:16953384

\section{Terms of Use}

This article was downloaded from Harvard University's DASH repository, and is made available under the terms and conditions applicable to Other Posted Material, as set forth at http:// nrs.harvard.edu/urn-3:HUL.InstRepos:dash.current.terms-of-use\#LAA

\section{Share Your Story}

The Harvard community has made this article openly available.

Please share how this access benefits you. Submit a story.

Accessibility 
2. Piot $\mathbf{P}$, Quinn TC, Taelman $\mathbf{H}$, et al. Acquired immunodeficiency syndrome in a heterosexual population in Zaire. Lancet $1984 ; 2: 65-9$.

3. Van de Perre $P$, Rouvroy $D$, Lepage $P$, et al. Acquired immunodeficiency syndrome in Rwanda. Lancet 1984; 2:62-5.

4. Brun-Vézinet F, Rouzioux C, Montagnier L, et al. Prevalence of antibodies to lymphadenopathy-associated retrovirus in African patients with AIDS. Science $1984 ;$ 226:453-6.

5. Update: acquired immunodeficiency syndrome - United States. MMWR $1985 ; 34: 245-8$.

6. Van de Perre P, Clumeck N, Carael M, et al. Female prostitutes: a risk group for infection with human T-cell lymphotropic virus type III. Lancet $1985 ; 2: 524-7$.
7. Obel AOK, Sharif SK, McLigeyo SO, Gitonga E, Shah MV, Gitau W. Acquired immunodeficiency syndrome in an African. E Afr Med J 1984; 61:724-6.

8. D'Costa LJ, Plummer FA, Bowmer I, et al. Prostitutes are a major reservoir of sexually transmitted diseases in Nairobi, Kenya. Sex Transm Dis 1985; 12:64-7.

9. Jaffe HW, Choi K, Thomas PA, et al. National case-control study of Kaposi's sarcoma and Pneumocystis carinii pneumonia in homosexual men: I. Epidemiologic results. Ann Intern Med 1983; 99:145-51.

10. Rogers MF, Morens DM, Stewart JA, et al. National case-control study of Kaposi's sarcoma and Pneumocystis carinii pneumonia in homosexual men. 2. Laboratory results. Ann Intern Med 1983; 99:151-8.

\title{
SPECIAL ARTICLE
}

\section{PREGNANCY DURING RESIDENCY}

\author{
Maureen Sayres, M.D., Grace Wyshak, Ph.D., Geraldine Denterlein, B.S., \\ Roberta Apfel, M.D., M.P.H., Eleanor Shore, M.D., M.P.H., and Daniel Federman, M.D.
}

Abstract To identify possible barriers to women physicians who wish to combine parenting with medical careers, we studied 56 of 64 pregnancies from the past 10 years in 63 of 66 Harvard-affiliated residency programs. Pregnancies during residency were common (one in eight married women in 1983) and were usually planned (77 percent). Most institutions were unprepared for pregnancies among members of the house staff; four fifths of the programs had no maternity-leave policy. No one quit a residency program because of pregnancy, and pregnancy rarely affected achievement of board certification. Wheth-

$\mathrm{M}$ EDICAL education has undergone profound changes in the past few decades. A house officer used to be an unmarried young man in a starched white uniform who performed his medical duties while residing in the hospital for several years. Today, however, a glance around medical training settings may reveal a resident in thoracic surgery rushing out of a late-scheduled operation to pick up his child at a day care facility or a medical resident in her seventh month of pregnancy running to a resuscitation in the intensive care unit. An increase in the number of women in all workplaces has had two major effects. First, few wives remain at home while their husbands pursue demanding medical careers, thus leaving those men with more responsibilities at home. Second, women and their natural roles as childbearers have introduced new variables into the training environment.

The conflicting roles of women physicians with children have been addressed in the medical literature. ${ }^{1-10}$ In 1983, the ad hoc Committee on Women Physicians of the American Medical Association conducted a nationwide survey of pregnancy during residency. ${ }^{11}$ The committee found that about two thirds of the women

From the Harvard Medical School, Boston. Address reprint requests to Dr. Sayres at the Office for Parenting of the Office for Academic Careers, Rm. 514, Bldg. A, Harvard Medical School, 25 Shattuck St., Boston, MA 02115.

Supported in part by the Harvard Medical Center and the Office for Academic Careers. er the pregnant women found pregnancy during residency a "pleasant" experience was determined largely by whether the program director was supportive, whether the issue of pregnancy was openly discussed within the program, and whether the woman was permitted to return to work on a part-time basis for the first weeks after maternity leave.

We conclude that pregnancy within residency programs should be expected and planned for and that if proper arrangements are made, it need not be a major problem for either the training program or the pregnant resident. (N Engl J Med 1986; 314:418-23.)

physicians in practice had children. Almost half had had their first child during training, and a quarter had had a second child during training. Few women reduced their working hours during pregnancy, and just under half the residency programs in the country had formal policies regarding maternity leave.

In this study of pregnancy at one group of institutions, we specifically addressed hours of work, frequency of pregnancy, maternity leave, attrition, board certification, and perception of the experience by three groups - program directors, pregnant residents, and "other" residents. Having recognized some problems, we aimed to make appropriate changes in our own institution.

\section{Methods}

\section{Subjects}

Permission to conduct this study was obtained from the Harvard Medical Center, an organization of the Harvard Medical School and its affiliated medical institutions. Three groups were identified for study: residency program directors, pregnant residents, and "other" residents.

All 66 directors of residency programs in the 15 hospitals in the system were sent questionnaires. The length of the residency programs ranged from one to six years.

To identify the group of pregnant residents, we obtained from each residency program a list of all residents who had been noticeably pregnant (we did not study miscarriages or abortions) over the past 10 years, including anyone who may have left the program because of pregnancy. We also contacted former directors of residency programs for cross-checks. The directors provided the names 
and addresses of 73 women whom they believed to have been pregnant during their residency in the past 10 years. This presumptive identification was verified in 64 of the cases; in the others, the directors had mistaken a pregnancy among the women on the staff or with fellowships for one among the residents or had misremembered the resident. Six of the women studied had had two pregnancies during residency; for the purposes of data analysis, however, they were counted only once.

The "other" residents in our study were 123 men and nonpregnant women in postgraduate years 1 to 6 who were randomly selected from the roster of spring 1983 and were residents in the Harvard system.

\section{Questionnaire}

We used a questionnaire that was designed to elicit both factual and attitudinal data. The factual questions varied according to the group studied. The attitudinal data were obtained by asking all three groups the same questions, which could be answered "yes" or "no." In addition, those in the pregnant resident group were asked whether their pregnancy had elicited encouragement or hostility from their colleagues and program directors.

\section{Statistical Analysis}

The data analysis included a chi-square test for differences in categorized data. Discriminant analysis was performed to determine how one or more independent variables could be classified to discriminate between two groups.

\section{Results}

\section{Background Data}

Sixty-three of the 66 residency directors (95 percent) and 56 of the 64 women ( 88 percent) who had been pregnant during residency training in the past 10 years participated in the study. Among the residents in Harvard-affiliated residency programs in 1983, 25 percent were women (Table 1). The means for age (31 years) and hours of work per week (95) were the same for men and women. The men were more likely than the women to be married $(\mathrm{P}<0.001)$. A distribution by specialty of women residents in the Harvard-affiliated programs, as compared with the national average percentage of women residents in those specialties, is shown in Table $2 .{ }^{12,13}$ Women were most highly represented in obstetrics-gynecology, pediatrics, psychiatry, and pathology. Eighty-six percent of the pregnancies occurred in 1978 to 1983 . In 1983, there was one pregnancy for every 25 women residents or one for every 8 married women residents.

In the group of "other" residents, 58 of 123 (47 percent) responded to the questionnaire.

\section{Data on Pregnant Residents}

Seventy-seven percent of the women said that their pregnancies were planned. The reasons given for becoming pregnant during residency included the woman's own personal needs (76 percent) and age (64 percent). Seventeen percent of the pregnancies began during postgraduate year 1,29 percent during year 2,29 percent during year 3 , and 25 percent during years 4 to 6 .

Sixty-three percent of the women took no time off before the birth of the baby (range, 0 to 12 weeks; mean $\pm \mathrm{SE}, 1 \pm 0.3$ ). Leave after the birth of the baby
Table 1. Demographic Data from Spring 1983 Harvard Medical School-Affiliated Residency Programs.

\begin{tabular}{lcc}
\hline \hline & MEN & WOMEN \\
& 972 & 322 \\
No. of residents & 63 & $53^{*}$ \\
$\begin{array}{l}\text { No. of programs in which each } \\
\text { sex was represented }\end{array}$ & 31 & 31 \\
Mean age of residents (yr) & 44 & $31 \dagger$ \\
Percent married & 95 & 95 \\
Mean no. of hours worked/wk & & \\
\hline
\end{tabular}

*Among the 10 programs with no women, several neurosurgery and thoracic surgery programs had never admitted a woman.

$\dagger \mathrm{P}<0.001$.

ranged from 0 to 36 weeks (mean and median, 8 weeks; SE, \pm 0.8 ; mode, 12). Seventeen percent of the pregnant women thought that they did not receive their usual fringe benefits during their leave, and 33 percent were granted less than eight weeks of leave because the amount of time they were permitted to take off was limited by their programs. The range for amount of paid leave, including sick leave, was 0 to 15 weeks (mean, $5 \pm 1$; median, 6 ); nearly 20 percent had no paid leave. Within each hospital, departments often varied considerably in the amount of leave granted; in one hospital, an obstetrics-gynecology resident received no leave, whereas a pathology resident received 14 weeks of paid leave. Many residents worked double duty in anticipation of leave and used vacation time for leave. When the residents were asked how much time they would have preferred to take for maternity leave, the average response was three weeks more than they had taken. All the residents returned to work after their pregnancy leave; 68 percent returned to full-time work (mean, 95 hours per week), and 23 percent returned to part-time work for several weeks (working from 10 to 80 hours per week) and then resumed full-time work. Nine percent had worked out a part-time residency schedule within their programs, which they began post partum.

At this time, each specialty board has its own requirements for the number of weeks to be worked each year in order for residents to be eligible for certification. ${ }^{11}$ Board certification was not affected by maternity leave for 90 percent of the women in our study; the other 10 percent worked extra months to make up missed time.

\section{Attitudes toward Pregnant Residents}

Seventy-six percent of the women who had been pregnant during residency said that they had received some encouragement from their program directors, and 93 percent said that they had received some from their fellow residents. At the same time, 40 percent said that their pregnancy had elicited some hostility from their program directors, and 41 percent said they had felt some hostility from their fellow residents.

When asked to rate their experience, 43 percent of the pregnant residents rated it as pleasant, 43 percent rated it as tolerable, 9 percent wished it had been better, and 5 percent said it was miserable. For the 
Table 2. Women in Residency Programs in Spring 1983 in U.S. and Harvard Medical School-Affiliated Programs According to Specialty.*

\begin{tabular}{lcc}
\hline \hline \multirow{2}{*}{ SPECIALTY } & \multicolumn{2}{c}{ Programs } \\
& $\begin{array}{c}\text { HARVARD } \\
(\mathrm{N}=1294)\end{array}$ & $\begin{array}{c}\text { U.s. AVERAGES } \\
(\mathrm{N}=59,225)\end{array}$ \\
& \multicolumn{2}{c}{ percentage of women } \\
& 55 & 34 \\
Obstetrics-gynecology & 42 & 32 \\
Pathology & 39 & 38 \\
Psychiatry & 35 & 46 \\
Pediatrics & 29 & 23 \\
Internal medicine & 22 & 22 \\
Radiology & 18 & 22 \\
Anesthesiology & 9 & 9 \\
Surgery and surgical subspecialties & 8 & 16 \\
Ophthalmology & 25 & 24 \\
$\quad$ Overall & & \\
\hline
\end{tabular}

*A review of spring 1985 data revealed few changes in the percentage of women.

data analysis, we divided the perception of the experience into two groups - "pleasant" and "unpleasant." Discriminant analysis showed that 96 percent of the residents could be classified correctly into the "pleasant experience" and "unpleasant experience" groups on the basis of a combination of variables. The four combinations of variables associated with a "pleasant" experience were the attitude of the residency director, which included the presence of encouragement and support, a willingness to help with needed arrangements, an expression of interest, and minimization of open hostility or denial of the pregnancy; the attitude of fellow residents, which included the presence of encouragement, help with needed coverage, and minimization of hostility, resentment, or isolation from the resident group; open discussions of pregnancy in the residency program; and a return to work on a part-time basis at first (instead of full-time).

\section{Data on Program Directors}

Fifty-nine of the program directors were men; four were women. Fifty-four percent of the directors had had a pregnant trainee in their program. Twenty-two percent of the programs reported that they had a formal maternity policy.

\section{Comparisons of Attitudinal Data}

All three study groups were given a list of hypothetical problems (Table 3) and asked to state whether they thought these problems could be associated with pregnancy during residency (yes or no). About half the respondents in all three groups said that the pregnancy of a resident created administrative problems, such as scheduling difficulties, for the departments. "Resentment among fellow house staff" was perceived by all groups, but more often by those in the pregnant resident group than by either the directors $(\mathrm{P}<0.01)$ or the other residents $(P<0.01)$. The directors (faculty and administrators) did not often report resentment on their own part, but it was perceived at a signifi- cantly higher level by the pregnant residents $(P<0.01)$ and the other residents $(\mathbf{P}<0.01)$. Program directors without experience with pregnant trainees predicted a much greater influence on the continuity of the program $(P<0.01)$ and on training $(P<0.01)$ than did the directors who had actually had pregnant trainees in their program. The other residents were less likely than the program directors to perceive that "the training of the pregnant resident had suffered" $(P<0.01)$.

\section{Discussion}

The excellent response rate among residency directors and women who had been pregnant during residency makes it possible to draw substantial conclusions about the experience of pregnancy in Harvard-affiliated residency programs. A comparison of our data with national statistics and with data from the American Medical Association suggests that our experience with resident pregnancies does not vary greatly from the national one. ${ }^{11,12}$ Residency programs can accommodate pregnancies, and women have managed to meet their work responsibilities while pregnant, with a minimum effect on their programs. But the data also reveal serious legal, institutional, and personal problems.

First, residency scheduling currently does not take into account any of the inevitable events of life that affect both men and women and result in lost time for the program - accidental injuries, illnesses such as hepatitis, and deaths of family members. Pregnancy is only one example of such events, and it is the most predictable. Because there is no formal mechanism for handling all these occurrences, they are experienced as disruptions that create considerable stress in an already high-pressure system. There is clear evidence of this stress in our study. Although most of the other residents and the directors were "encouraging" toward their pregnant colleagues, they were also noticeably hostile when faced with increased night call or when having to schedule maternity leaves into a system not designed to include them. "Resentment among fellow house staff" was perceived significantly more often by pregnant residents than by the directors or the other residents themselves. This could reflect an inherent bias in our study. Data on attitudes of the other residents were gathered only in 1983, whereas some of the women in the pregnant residents group were responding to circumstances that had occurred several years earlier, when attitudes toward pregnancy may have been less favorable. These pregnant women may also have been overly aware of any effect that their pregnancy may have had on their colleagues, or the other residents and program directors may have underestimated their own resentment of the pregnant residents. The possible presence of denial of resentment on the part of the program directors is corroborated by the finding that these respondents said that they did not resent the pregnancy, yet such resentment was reported by three times as many re- 
spondents in both the pregnant-resident and otherresident groups than in the group of program directors. The data also reveal that program directors without experience with pregnant trainees have unwarranted fears about the influence of a pregnancy on residency programs. This attitude could be additional evidence for the observation that the prospect of any perturbations in the already pressured system creates negative feelings. It may also represent a different view of women's roles.

Our second observation is that institutions have often been unprepared to meet the specific needs of pregnant physicians. Pregnancy is a common event, yet four fifths of the programs we surveyed had no policy on maternity leave. In the absence of a formal policy, some women were limited by their programs to little or no leave, or they lost their usual fringe benefits during their leave. Federal and state laws were often unheeded. To protect their health, however, women residents should be considered employees and should be given at least the protection provided by state and federal laws regarding maternity leave.

Federal law prohibits discrimination against pregnant employees. The Federal Pregnancy Discrimination Act of 1978 requires an employer to treat pregnant employees in the same way as persons who are not in such a condition but who are similar in their ability or inability to work. The act forbids discrimination against pregnant women in hiring, reinstatement, firing, compensation, entitlement to leave, and the usual fringe benefits. ${ }^{14}$ The law does not specify the amount of maternity leave to be granted, but it does say that if an employer offers unpaid leave or paid sick leave to nonpregnant employees for illness, disability,

Table 3. Perceptions of Problems That Could Be Associated with a Pregnancy during Residency.

\begin{tabular}{|c|c|c|c|c|c|}
\hline \multirow[t]{3}{*}{ Problem* } & \multicolumn{5}{|c|}{ RESPONDENT GROUP } \\
\hline & $\begin{array}{l}\text { ALL PROGRAM } \\
\text { DIRECTORS }\end{array}$ & $\begin{array}{l}\text { PROGRAM } \\
\text { DIRECTORS } \\
\text { WITHOUT } \\
\text { EXPERIENCE } \dagger\end{array}$ & $\begin{array}{l}\text { PROGRAM } \\
\text { DIRECTORS } \\
\text { WITH } \\
\text { EXPERIENCE } \dagger\end{array}$ & $\begin{array}{l}\text { PREGNANT } \\
\text { RESIDENTS }\end{array}$ & $\begin{array}{l}\text { "OTHER" } \\
\text { RESIDENTS }\end{array}$ \\
\hline & \multicolumn{5}{|c|}{ percentage of "yes" answers } \\
\hline $\begin{array}{l}\text { Administrative problems such as sched- } \\
\text { uling difficulties were created } \\
\text { for the department }\end{array}$ & 51 & 52 & 50 & 57 & 58 \\
\hline $\begin{array}{l}\text { The pregnancy created resentment } \\
\text { among fellow house staff }\end{array}$ & 30 & 19 & 38 & $67 \ddagger$ & $38 \S$ \\
\hline $\begin{array}{l}\text { The pregnancy created resentment } \\
\text { among faculty or administration }\end{array}$ & 15 & 20 & 12 & $47 \ddagger$ & 439 \\
\hline $\begin{array}{l}\text { The program is forced to recruit } \\
\text { and hire a new resident to take } \\
\text { her place with little notice }\end{array}$ & 35 & $54 \|$ & 22 & $4 \ddagger$ & $22 \S$ \\
\hline $\begin{array}{l}\text { The training of the pregnant res- } \\
\text { ident suffered substantially } \\
\text { because of her pregnancy }\end{array}$ & 35 & $57 \|$ & 19 & 15 & $4 \pi$ \\
\hline
\end{tabular}

*Other problems were studied but did not result in this level of statistical significance.

f "Without" and "with" experience pertains to whether the program director had ever had a pregnant resident in his or her residency program.

$\ddagger \mathrm{P}<0.01$ as compared with all program directors.

$\Uparrow \mathrm{P}<0.01$ as compared with all program directors.

$\| \mathrm{P}<0.01$ as compared with program directors with experience. or personal reasons, pregnant employees must be granted leave and compensation according to the same standards. Massachusetts law further mandates that persons who take eight weeks or less of leave have the right to return to a previous or comparable position (in most cases). ${ }^{15}$ Employee benefits, including sick time or disability insurance payments, must be provided to pregnant employees on a nondiscriminatory basis.

We recommend a period of three months of maternity leave for all women residents who wish to take it, for several reasons. First, 12 weeks was the mode for the maternity leaves in our study, and it clearly can be tolerated by many programs if there is time to prepare for it; it is also near the mean value for leave time that the women in our study preferred. Second, research in child development has identified a period of intensive development of the mother-child relationship during the first four months of life, after which separation is easier. Third, a leave of 12 weeks would allow women residents time to rest and care for the baby and to prepare to return to work for 95 hours per week - twice the numbers of hours worked by most women employees. Fourth, many day care centers will not accept infants who are less than three months old. Fifth, most other industrialized nations provide a minimum of 12 weeks of leave $^{17}$ (in England, for example, the law allows a minimum of 18 weeks' leave; in France, it allows 16 weeks' leave.)

Finally, a physician mother should not be so pressured by rigorous career demands that she cannot spend "needed" time with her baby. The "needed" amount of time is indeed arguable, with considerations ranging from the service demands of the training program to the individual desires of the couple and the developmental needs of the baby. But residency programs currently apply pressures that minimize considerations other than those of the programs. The women in our study worked until the time of delivery in most cases, did double duty, used vacation time before and after the birth to make up for lost time, and returned to work an average of eight weeks after delivery for an average of 95 of the 168 hours in a week. The current climate of residency is in direct conflict with the realities of a young person's life - the time needed to develop a relationship with a partner; the age limits of fertility; the time needed to carry, breast-feed, and care for a baby; and the need to sleep in order to function effectively..$^{18,19}$ Although this contradiction has existed for many years, the 
presence of so many women in medicine today brings the issues much more into focus.

What solutions do we propose for these problems? All our conclusions point to the need for more flexibility in residency programs; yet, given the current budgetary climate, most directors have no new money to support such flexibility. We recommend an investigation into a fundamental change in the current pressures of residency programs. Until some changes can be made, however, we are pursuing several avenues at our institution. For example, to provide payment for maternity leave, residents may be able to use the equalized short-term disability plans recently developed by insurance carriers. Some of these carriers provide full salary for maternity leave at a very low premium for the "disabling" period, which can begin as early as a week or two after delivery. This form of payment for maternity leave would be particularly helpful to residents who, as short-term employees, have not accumulated sick-leave time. Because physicians have a very low insurance risk in this category and return to work quickly, the plan could be offered either at the place of employment or through national residents' or physicians' groups.

To provide coverage at the hospital during a resident's leave, we have found several solutions to be successful. An extra month of flexible time (e.g., for consultation or electives) can be built into many residency programs to provide time for maternity and paternity leaves and for an identified period that would be used as backup coverage in case of any resident's absence. The hiring of an extra person, such as an M.D./Ph.D. who does six months of laboratory work and six months of clinical work, has also provided for additional coverage at low cost to hospitals. Other options include paying others to take extra night call or having each program in an institution or set of hospitals contribute a small sum to a "pooledrisk" source, which would then make payments for coverage and maternity leave.

In the Harvard medical area, we have set up a special office for parenting to emphasize our support to those combining medicine and parenting. In one year, we have provided services to 600 families and 50 program directors; equal numbers of men and women, and faculty and trainees have used the office. We have gathered helpful information for program directors (e.g., information on safe radiology rotations for pregnant residents) and parents (e.g., information on inhome child care, a network of other physician parents in various neighborhoods and hospitals, and an informal exchange for those seeking part-time work). In addition, we distributed to program directors, faculty, and trainees copies of the state and federal laws and guidelines for maternity leave that apply to Harvard faculty.

The results of our study suggest some changes that pregnant women and program directors could make in order to improve the experience of pregnancy during residency. Program directors can establish a supportive climate in the program towards pregnancy, promote an open-minded and collegial discussion of pregnancy, and help women to make the needed changes to return to work gradually after a leave; announce at orientation the formal policies for maternity, paternity, and adoption leaves, as well as the provisions made by the department for coverage and payment of those leaves; anticipate life events (including pregnancies) and restructure a schedule that suits the specialty requirements but also provides some flexibility for absences; and work with other directors, department chairpersons, and administrators to investigate solutions to such problems as additional coverage, board-certification restrictions, and on-site day care facilities.

A woman resident who plans a pregnancy can notify her program director as soon as possible after becoming pregnant. Once pregnant, she can schedule the rotations that have more flexible hours and less demanding night-call hours for the time before and after delivery, establish for herself the minimum amount of time she needs with her child and work for changes needed to receive that time, and recognize the inherent conflict in residency scheduling and address this conflict with colleagues and directors, rather than work overly hard to compensate for a program's problem or regard a pregnancy as an "irresponsible" act. ${ }^{20}$

This study has characterized the experience of pregnancy during residency at a group of Harvardaffiliated teaching hospitals and has identified problems for both male and female residents that must be addressed. It is important that residency training programs reflect sensitivity to issues that are a natural and expected part of all our lives.

We are indebted to Ms. Dorothy Friendly and Ms. Maureen Rooney for technical assistance, to Dr. Peggy Morrison for computing assistance, to Anne Taylor, Esq., for legal counsel, to Drs. Clyde Evans, Alice Rothchild, Kathleen Thurmond, and George Vaillant for their assistance in preparing the manuscript, to the Joint Committee on the Status of Women and Drs. Mitchell Spellman and Donald Medearis for their continuing support of this work, and to Ms. Kathleen Turner of the American Association of Medical Colleges for help in gathering background information.

\section{REFERENCES}

1. Angell M. Women in medicine: beyond prejudice. N Engl J Med 1981; 304:1161-2.

2. Heins M. Medicine and motherhood. JAMA 1983; 249:209-10.

3. Nadelson CC, Notman MT, Lowenstein P. The practice patterns, life styles, and stresses of women and men entering medicine: a follow-up study of Harvard Medical School graduates from 1967 to 1977. J Am Med Wom Assoc 1979; 34:400-6.

4. Greganti MA, Fletcher SW. House staff pregnancy in internal medicine residencies. Ann Intern Med 1985; 102:123-5.

5. Auchincloss EL. Conflict among psychiatric residents in response to pregnancy. Am J Psychiatry 1982; 139:818-21.

6. Butts NT, Cavenar JO Jr. Colleagues' response to the pregnant psychiatric resident. Am J Psychiatry 1979; 136:1587-9.

7. Franco K, Evans CL, Best AP, Zrull JP, Pizza GA. Conflicts associated with physicians' pregnancies. Am J Psychiatry 1983; 140:902-4.

8. Shapiro J. Children during residency: it's easier if you're a man. J Am Med Wom Assoc $1981 ; 36: 227-31$. 
9. Benedek EP, Poznanski E. Career choices for the woman psychiatric resident. Am J Psychiatry 1980; 137:301-5.

10. Shapiro J. Pregnancy during residency: attitudes and policies. J Am Med Wom Assoc 1982; 37:96-7, 101-3.

11. Maternity leave for residents. Chicago: American Medical Association, 1984:1-21.

12. 83rd annual report on medical education in the U.S.: 1982-1983. JAMA 1983; 250:1546.

13. 85th annual report on medical education in the United States: 1984-1985. JAMA $1985 ; 254: 1590$

14. Title VII of the Civil Rights Act of 1964, 42 U.S.C. Sec. 2000e-(k), as amended P.L. 88-352, 78 Stat 253 (1978).
15. Massachusetts General Laws. Chapter 149, Sec. 105D.

16. Brazelton TB. Working and caring. Reading, Mass.: Addison-Wesley, 1985:60-7.

17. Kamerman S, Kahn AJ, Kingston P. Maternity policies and working women. New York: Columbia University Press, 1983:14-24.

18. Balk SJ, Yellin TG. Breast-feeding during pediatric residency: is "breast-fed is best fed" only for others? Pediatrics 1982; 70:654.

19. Moore-Ede MC, Czeisler CA, Richardson GS. Circadian timekeeping in health and disease. 2. Clinical implication of circadian rhythmicity. $\mathrm{N} \mathrm{Engl}$ J Med 1983; 309:530-6.

20. Joseph BW. Another interpretation of residents' response to pregnancy. Am J Psychiatry 1983; 140:267.

\section{MEDICAL PROGRESS}

\section{FATAL ASTHMA}

\section{Solomon R. Benatar, M.B., Ch.B., F.F.A. (S.A.), F.R.C.P. (Lond.)}

$\mathrm{A}^{\mathrm{s}}$ THMA has been recognized for more than 30 centuries, ${ }^{1}$ but only in the past 50 years has death from the disease attracted much attention. Floyer reported sudden death from asthma in an 18-month-old child in $1698 .^{2}$ In 1784 , Cullen wrote, "The asthma, though often threatening immediate death, seldom occasions it, and many persons have lived long under this disease. In many cases, however, it does prove fatal; sometimes very quickly and perhaps always at length." ${ }^{3}$ In contrast, Laennec, who made many observations on asthma, including the occurrence of nocturnal attacks, did not recognize that it could be fatal. At the beginning of this century, William Osler taught that acute attacks of bronchial asthma never caused death. ${ }^{4}$ In 1922 , death as a complication of asthma was highlighted when Huber and Koessler described pathological evaluations of the lungs in 21 fatal cases. ${ }^{5}$ An additional 176 deaths from asthma were reported in 1952, and a poorer prognosis was noted among patients whose asthma had begun after the age of 40 than among those who experienced their first symptoms before they were $25 .^{6}$ In 1953 , Williams reviewed 41 deaths from asthma known to him and 140 from the literature. More than 80 percent of the patients were older than 30 , and 50 percent of these had had asthma for less than five years. ${ }^{7}$ Similar observations were made by Houston et al. ${ }^{8}$ and Earle. ${ }^{9}$ In both those series extensive mucous plugging was found to be an almost universal feature at autopsy, and widespread detachment of ciliated epithelium was also prominent. ${ }^{8}$

Until 1953, very few of the 200 reported deaths from asthma occurred in children. In the next decade, however, this situation changed. In the 1960s, an "epidem-

From the Respiratory Clinic, Department of Medicine, the University of Cape Town and Groote Schuur Hospital, Cape Town, South Africa, where reprint requests should be addressed to Dr. Benatar.

Supported by a Coleman Bequest and the University of Cape Town Staff Research Fund. ic" of deaths among young persons with asthma was observed in the United Kingdom, ${ }^{10-12}$ New Zealand, ${ }^{13}$ Australia, ${ }^{14,15}$ and to a much lesser extent, in the United States. ${ }^{11,16}$ In the United Kingdom, the reported mortality from asthma among patients who were 5 to 34 years of age tripled between 1959 and 1966 (rising from 0.74 to 2.18 per 100,000 persons per year). Among those who were 10 to 14 years old, the mortality rate increased sevenfold, and asthma became the fourth most common cause of death in this age group. ${ }^{10}$

Death from asthma has also been documented in several long-term studies. In a 20 -year follow-up study of 648 asthmatic children, 23 died -10 (1.5 percent) from asthma. ${ }^{17}$ Blair described the natural history of asthma in 267 children who were under 12 years of age when they were first seen between 1941 and 1952 and whom he followed personally for more than 20 years (until December 1972) ${ }^{18}$ Seven of the patients died during this period - three from asthma. Thus, 1.1 percent died from asthma during the study - a rate that can also be expressed as 50 deaths per 100,000 asthmatic patients per year. ${ }^{18}$ Ogilvie reported a death rate of 7 percent among 1000 patients with asthma who were followed for an average of 10 years (range, 3 to 33). ${ }^{19}$ Among the 80 patients followed for 10 to 12 years by McCracken, 10 percent died, half of them from asthma. ${ }^{20}$

Despite these findings, there is a surprising lack of information on death from asthma in a recent issue of a review publication on the disease. ${ }^{21}$ References are made to three long-term follow-up studies of patients with asthma, ${ }^{22}$ but not to the fatal outcome of the disease in 1.1 to 7 percent of patients. ${ }^{17-19}$

\section{EPIDEMIOLOGY}

Asthma is a common disease; it affects approximately 3 percent of the population and produces considerable morbidity. Deaths from asthma are relatively uncommon, but they occur often and "unex- 